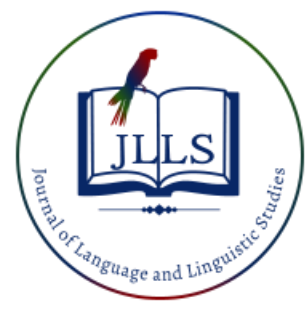

Available online at www.jlls.org

JOURNAL OF LANGUAGE AND LINGUISTIC STUDIES

ISSN: 1305-578X

Journal of Language and Linguistic Studies, 17(4), 2096-2110; 2021

\title{
The effect of gender on language use in British novels: A sociolinguistic study
}

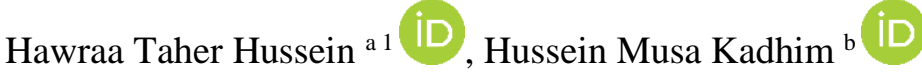 \\ ${ }^{a, b}$ Faculty of Education, Department of English Language, University of Kerbala, Iraq \\ APA Citation: \\ Hussein, H.T., \& Kadhim, H.M. (2021). The effect of gender on language use in British novels: A sociolinguistic study. Journal of Language \\ and Linguistic Studies, 17(4), 2096-2110. Doi: 10.52462/jlls.151 \\ Submission Date: $12 / 07 / 2021$ \\ Acceptance Date:25/09/2021
}

\begin{abstract}
The present study investigates the effect of the social variable, such as gender on language use in British novels. Precisely, it attempts to achieve the following aims: (1) Identifying the influence of the social variable, like gender on the linguistic choices of language used in British novels; (2) Finding out the differences and similarities in the use of transitivity's process types in the language of the novels by the British male and female narrators; (3) comparing the language use between the two selected samples in the light of the micro and macro linguistic strategies.
\end{abstract}

To achieve the aims of this study, it is hypothesized that: (1) Gender affects the linguistic choices in language of the British novels; (2) Generally, there are apparent differences and similarities between the two selected data in using some linguistic choices like material, mental, attributive-relational, and identifying-relational processes; (3) The British female narration tends to use the psychological processes more than the male one.

After all tasks of data collection were accomplished, the first step in analyzing the collected data began with analyzing the language of the two British novels which the researcher dealt with in this study using three analytical models through which the eclectic model was designed so as to achieve the objectives of the current study. For the purpose of analysis, two British novels were analyzed at micro and macro levels. At micro-level, lexical features based on Halliday's (2004) model, and grammatical features based on Quirk's (1985) framework, were analyzed. This was followed by the analysis of micro-level (superstructure) based on Labov's (1972) model.

Keywords: Sociolinguistics; Gender; Transitivity; Passivization; novel

\section{Theoretical Background}

\subsection{Introduction}

Some sociolinguists have a slant to avert defining sociolinguistics in an obvious way such as Labov who supposes that sociolinguistics is "strangely superfluous" because language, according to many linguists, is always social (1972, p. 183). This point of view is supported by Hudson (1996, p. 3) who mentioned two accurate reasons, which are: it is impossible to take the notion 'language $\mathrm{x}$ ' for granted since this per se is a social notion which is defined according to a set of people who speak $\mathrm{x}$, that is, language supposes society; and the second reason is that language has a social function both in that it is as a means of communication and a way of limiting social groups. On the other hand, this opinion is unacceptable by some linguists like Chomsky who confirms that a linguistic theory is fundamentally interested in a typical talker or hearer in a perfectly homogeneous speech society (Chomsky, 1965, p. 3). Therefore, not all linguists shed light on the social sides of language, and for that reason it may be

\footnotetext{
${ }^{1}$ Corresponding author:

E-mail address: alhisnawy1@gmail.com
} 
said that the term is used to refer to a group of associated domains which focus on the study of language in social contexts and identify it from those domains that are completely descriptive and historical in nature (Baker, 2010, p. 2).

In this respect, sociolinguistics deals with many topics such as how individual speakers use language, how people use language diversely in different cities or regions, and also how a nation decides what languages ought to be recognized in courts and education (Meyerhoff, 2006. P. 1). Some linguists claim that the term sociolinguistics must not to be seen as a single approach directed by a consistent impulse for the sake of an integral objective but kinda it is wide association of domains studying the intersections between language and society (Hazen, 2010, p. 7).

Consequently, we can say that sociolinguistics is sub-discipline linguistics that studies the relationship between social behavior and the behavior of the language. The main issues that sociolinguistics studies and discusses are: language variation, language characteristics, reviewing the language in social and cultural context, linking linguistic factors, social and cultural factors, the effect of social variables on the use of language, in addition to reviewing the social functions and the use of language in society (Soeparno, 2002, p. 25).

Regardless of the differences in points of view about sociolinguistics, some sociolinguists conclude that the main task of sociolinguistics is relating linguistic variation as the dependent variable with independent variables like linguistic environment, social categories or style (Chambers, 1995, p. 17). Furthermore, most sociolinguists are concerned with how people use language and for what they use it. Besides, they are concerned with documenting the different form of language, what it looks like and how it is structured. Over and above, those sociolinguists are also try to answer questions such as: who uses those different forms or language varieties? With whom do they use them? Are they acquainted with their choice? Why are some forms of language superior to others? Is there any relationship between the changing forms in the community of speakers? What type of social information do we associate with different forms in a language or different language varieties? To what extent can we change or control the language we use? (Meyerhoff, 2006, p. 2).

Based on the previous explanation, it can be concluded that sociolinguistics denotes to study of language that is related with the condition of a specific society. In other words, we can say that sociolinguists are concerned with both social and linguistic questions. Undoubtedly, some sociolinguistics research has more to say about both social and linguistic issues, but what makes someone's work distinguished sociolinguist is the fact that it has something to say about both linguistic and social structure (Meyerhoff, 2006, p. 2).

\subsection{Relations between Language and Society}

Language is a social phenomenon and a system of communication between individuals. An interest in human communication aspect in defining language means the way language is played out in societies in its whole range of functions. Language is not mere denotational, an idiom which denotes to the process of conveying meaning, indicating to events, thoughts or entities that exist outside language. A speaker will automatically give off signals relating to his/her social and personal background. Consequently, language is said to be an indicator of an individual's social class, gender, age, region of origin, education and many other things (Mesthrie et al., 2000, p. 5).

The field of language and society (sociolinguistics) is purposed to show how our use of language is dominated by such factors as race, age, education, gender, social class and others. The study of language and society (sociolinguistics) goes back to the middle of the twentieth century. Previously, there were many authors who commented on how the use of language was affected by related social factors like age, social class, gender, ethnicity and so on. When sociolinguists speak about language, 
we mean language as it is indeed used. This does not seem very difficult but in fact distinguishes us from ordinary people and other sections of linguistics (van Herk, 2012, p. 20). Sociolinguists believe that language is a social being that obtain its meaning and power through the speaker's participation in the language-using groups. This means specifying what people are doing with the language at any specific time (van Herk, 2012, p. 20).

\subsection{Language variation}

Language differs in many ways. One way to describe some of the differences is by saying that talkers of a specific language occasionally talk diverse dialects of that language. Since language is a personal and a social property at the same time, each individual or social group has a set of characteristics in his dialect that may distinguish it from the other group. Linguistic variation is related with religious, ethnic or regional affiliation, gender, age, and social class. Language detects the speaker's level of education too, as they all form the individual identity and detect his/her membership. The term dialect here is important in our study of sociolinguistics, and also to expand the use of it from studies of regional difference to studies of social difference. Thus, it is probably to speak of each "regional dialects and social dialects of a language." Thoroughly, as a regional dialect, distinguishes the inhabitants of an area from the inhabitants of other areas, whereas, the social dialect is a diverse group connected with a particular group or social class which distinguishes that group or class from other groups or classes (Wardhaugh, 2006, p. 135).

\subsection{Linguistic variables}

Linguistic variable is derived from Labov's work (1963) with other studies of various sociolinguists like Wardhaugh (2006), Wolfram (1969), Meyerhoff (2006), and many others. A linguistic variable is a linguistic component that has variables which can be identified. For example, "words such as fishing and singing are occasionally pronounced as fishin' and singin'." The final voice of these words are known the linguistic variable 'ng' with two variants "[ $\left[{ }^{\mathrm{g}}\right]$ in fishing and [n] in fishin." Another instance of a linguistic variable is seen with words like "far and farm"; in such words, the 'r-sound' is occasionally pronounced lesser. So, there is "the linguistic variable (r) with two variants $\varnothing$ (which pronounced zero) and [r]." Many linguists use a number of linguistic variables according to this variation. The variable (ng) has been vastly used (Wardhaugh, 2006, p. 143).

Labov (1972, p. 8) points out that a linguistic variable is the substitution of shapes or layers of shapes in language. A major definition of linguistic variable is two or more ways that saying the same thing. An accurate definition also states that linguistic variables must be structural and incorporated into a larger system of working units. Labov mentions that linguistic variables do not differ in a particular speech community, whether lexical, phonological, discursive, syntactical or morphological, randomly, but methodically. Since it is systemic, this behavior can be shaped quantitatively (1963, 1969).

Research on language variation and change starts with the surveillance that language is variable in nature. When speakers talk, they begin to make choices and exchange between these choices such as, the use of forms that hit the ear as non-standard, uncommon, dialectal, or modern.

\subsection{The social variables}

At the essence of sociolinguistics is the fact that human communities are inwardly diversified, whether by age, social class, or gender. These distinctions and there are many others like education, ethnicity, etc., are at a macro level that is wide groups in which people can be classified (Llamas et al., 
2007, p. 51). Meyer (2009, p. 17) points out that the importance of social variables is clearly evident in the various types of efforts that speakers make when they request something from the receiver which is largely determined by the different social roles that the speakers play: gender, level of education, age, social class, and so on.

On the other hand, Blum-Kulka, et al (1989b, p. 4) illustrate that these variables could be classified into two sets; the first one generates individual variation whereas the second one creates situational variation. The first set involves personal variation like age, level of education, sex, and type of profession. The variables of this set contain of constant values which do not alter when the context alters for example, they are not sentient of context. The second set involves situational variables such as social dimension, intensity of offense, relative power, and so on. The variables of this set are personal and so they are context sentient in that the value of each variable owned by the speaker in a given context will possibly alter when the context alters.

\subsubsection{Gender}

Gender as a social gathering or a feature of social identity, has been of great importance in sociolinguistics and other related fields such as social psychology and linguistic anthropology. The term "SEX" has been found in previous studies in 1960s and 1970s, but gender has been favored since around the 1980s, reflecting a combined distinction in the social sciences between 'sex' as a biological feature and 'gender' as a social feature. Sex and gender have been social variables in many studies of variationist of language change and language variation; both of them were also interested in Interactive sociolinguistics studies that specified "masculine" and "feminine" styles of conversation. Today, LANGUAGE AND GENDER is considered a staple multi-specialty research field. The concentrate of previous sociolinguistic research has been on identifying gender differences in the use of language. For example, variationist studies discovered that women used more prestige and men more used of colloquial linguistic features. Several studies have also concentrated on gender and power, for instance, male dominance over mixed interactions between the genders. These procedures take gender as a social category previously existing and check how it correlates to the use of language (Swann et al., 2004, p. 122).

Cheshire points out that gender is the social counterpart of biological sex (2002, p. 427). Among all sociolinguistic norms, the most obvious and symmetrical is the disparity between men and women (Labov, 1990, p. 205). This connection has been mentioned everywhere in a number of ways The following notes illustrate that.

- "Women use less stigmatization forms than men in cautious speech, and are more ticklish than men to style of prestige" (Quoted in: Labov 1972c, p. 243) (Tagliamonte, 2012).

- "Females are more ticklish than males to linguistic forms with social evaluation" (Wolfram, 1969, p. 78).

- "Wolfram and Fasold (1974, p. 93) point out that females appear more consciousness of prestige criterions in both their realistic speech and behaviors towards speech".

- $\quad$ "Cameron and Coates (1988, p. 13) mention that women on medium swerve less from the prestige level than men".

- "Trudgill (1983, p. 161) states that women, permitting for the other variables like social class, age, and education, originate on average linguistic forms that are nearer to those of the standard language or possess a greater status than those made by men".

- "Women select linguistic features with a comparatively broad geographical allocation, supra local or national standards" (Cheshire, 2002, p. 430). 


\section{Methodology}

\subsection{Population, Sampling and Sample}

The population which is targeted by this study is the British country. Consequently, a representative sample of this population is selected from this country for study. The sample is a subset of the target population that the researcher plans to study in order to circulate it about the target population (Creswell, 2014, p. 160; 2012, p. 142). The population, in research terminology, may be explained as an overall group of institutions, objects, individuals, cases, etc. that have common characteristics of interest to the researcher. For example, in this study, the researcher is interested in studying the language of famous British novels.

In this research, the population sample was two novels which were from Britain country. These samples are opted as analysis for this study. Each sample contains one element. The samples should have different representation of gender, age and social class in order not only to obtain different statistical data of gender, age and linguistic behavior of social class, but also to supply the reader with an in-depth description about the language variation among this specific group of men and women who have different social background. Table 1 illustrates a brief information about the two samples.

Table 1. A brief information of samples

\begin{tabular}{|l|l|l|l|l|l|l|}
\hline Samples & $\begin{array}{l}\text { Name of } \\
\text { Author }\end{array}$ & Nationality & $\begin{array}{l}\text { Language } \\
\text { of Author }\end{array}$ & Age & Gender & $\begin{array}{l}\text { Social } \\
\text { Class }\end{array}$ \\
\hline $\begin{array}{l}\text { Sample 1: We Are } \\
\text { Not Alone }\end{array}$ & $\begin{array}{l}\text { James } \\
\text { Hilton }\end{array}$ & British & British & 54 & Male & $\begin{array}{l}\text { Middle } \\
\text { Class }\end{array}$ \\
\hline Sample 2: N Or M? & $\begin{array}{l}\text { Agatha } \\
\text { Christie }\end{array}$ & British & British & 85 & Female & $\begin{array}{l}\text { Upper- } \\
\text { Middle- } \\
\text { Class }\end{array}$ \\
\hline
\end{tabular}

\section{Sample 1 We Are Not Alone}

We Are Not Alone is a famous novel written by James Hilton in 1937, and it is one of his more dismal works that depicts the tragic consequences of hatred against foreign in England before the First World War. James Hilton is a British novelist, born in Leigh, Lancashire, England on September 9 (1900), and died on December 20 (1954). James was born to a father, who worked as the headmaster of school in Walthamstow. He was studied in the Monoux Walthamstow's school, until 1914, then he studied at the Leys School in Cambridge, and finally at the Christ's College in Cambridge, as he wrote his first novel and was received an honors degree in English literature. James Hilton produced a series of highly regarded novels that turned into much appreciated films such as Lost Horizon (1937), Random Harvest (1942), etc. Finally, he moved to the United States and died in Long Beach in California 1954 from liver cancer. In each of Hilton's novels, there is something that makes it worth reading. The first is the perfect romantic fabulous informal writing style. Then, there is Willa Cather's technique of allowing the reader to reach the climax under the surface, to signal at things to come. This is particularly correct in the novel 'We Are Not Alone'. We Are Not Alone: is an influential picture of the trials and tribulations of one family on the period of the First World War. The novel deals with a lovable doctor called Newcome lives in a little English city. A bad relationship with his wife and son led him to develop an affair with a German dancer named Leni, whom the family takes on as a housekeeper. When the wife of Newcome, Jessica, is murdered under doubtful circumstances, both Leni and Dr. Newcome are under suspicion. The town's bias versus Leni as a German led them to indictment her and doctor Newcome in spite of just circumstantial proof. Finally, the little doctor and the young woman who was accused with him of the murder of Newcome's wife, were executed. The 
case caught a great deal of attention at the time, not only among the general public but also in the legal departments. The characters of his novels might be isolated, doomed to fate, lost or even face certain death, but Hilton's message is obvious: We Are Not Alone. It is not a suitable, over-emotional statement intended to provide an easy relief (in spite of his novel certainly offered solace to a weary readership between wars). Rather, his message resonates as the purest form of storytelling: the locution of shared experiences that lead us to more wisdom in times of distress (Hilton, 1937, p. 1).

\section{Sample 2 N OR M?}

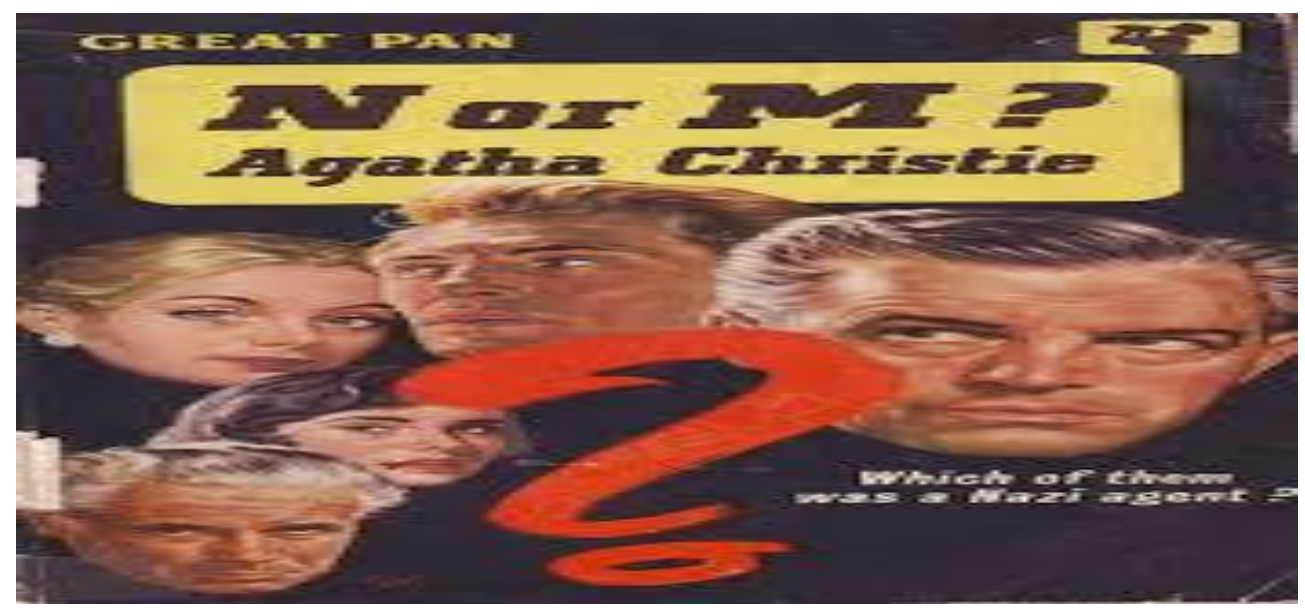

$\mathrm{N}$ or M? is a British novel written by Agatha Christie and published in the UK by the Collins Crime Club in November 1941. The most famous British woman writer, Agatha Christie, was born as "Agatha Mary Clarissa Miller" on $15^{\text {th }}$ September 1890 into a wealthy upper-middle-class family in Torquay, Devon, in the southwest part of England, and died on 12 January 1976 in Wallingford, England. Agatha Christie was not just a famous writer but also the bestselling novelist of all time, whose books have sold more than 100 million copies and have been translated into about one hundred languages. During the First World War, she worked in a Devon hospital, tending to troops coming back from the moats. Although raised by a wealthy upper-middle-class family in England, its language has always been simple, with a writing style that every reader can understand and entertain. Despite simple in style, its dramatic plots and sub-plots challenge readers to find out 'who did it' before the story ends (Christie, 2003b, p. i). Christie's novel 'N or M' differs from the other of her works as it takes place during World War II, where espionage was working with full force. While the Royal Air Force was laboring hard to avoid fierce attacks by the German Air Force, Britain, however faced the danger of the spread of spies, so the war became internal and external, as the Nazis worked in an invisibly and total confidentiality, and it seemed that they were well trained to play the role of the citizen normal British. With the increasing frequency of events, the Intelligence Services appointed two spies, Tommy and Tuppence Beresford, and sent them on a dangerous mission to the San Souci Hotel, where information arrived about the presence of a man and woman among the inmates, but they are Nazis working for the enemy. It seems that Mr. and Mrs. N and M have the ability to stealth and get rid of censorship, and they have just killed one of the most important British agents, which means that it is a daunting task. Briefly, the novel $\mathrm{N}$ or M? is about a couple named Tommy and Tuppence Beresford, who are summoned by the British Secret Service to arrest one of Hitler's most dangerous clients, whether known by the code-name N or M. The events take place in a boarding house (the Sans Souci) at a seashore resort in south England. Tommy and his wife Tuppence arrived at Sans Souci under an alias Mr. Meadows (Tommy) and Mrs. Blenkensop (Tuppence). They pretended not to know each other in order to seek out, by the help of long conversations with visitors and by many hearsays 
which are spread around, who acts natural and does not pretend to be another person and secret agent. Agatha Christie has succeeded to create a group of characters in Sans Souci that seem not harmful and menacing at the same time. In the end, therefore, it is not surprising to find that of the twelve residents, there are three clients working on behalf of British Intelligence and one Nazi client. Finally, the identity of both $\mathrm{N}$ and $\mathrm{M}$ was revealed at the end of the novel: " $\mathrm{N}$ " is a prominent Germany spy, who was shot by British Intelligence at the end of the novel while threatening Tuppence's life. " $\mathrm{M}$ " is his conspiring wife (Christie, 1941).

\subsection{Modal of Analysis}

\subsubsection{Grammar and Semantic (Quirk 1985 and Halliday 2004)}

Voice is one of the grammatical classes of a verb, apart from tense, mood and aspect. It may be defined as a grammatical class that makes it potential to present the action of a sentence in one of the two ways without altering the stated facts (Quirk et al., 1985, p. 159). Voice may be active or passive. According to (Veselovská \& Emonds, 2011b, p. 8), the fundamental element of a sentence according to passive is an object. It relies on the parity of the verb, which defines its syntactic and semantic subclassification. Essentially, sub-classification imposes the mandatory complementation of the verb.

Halliday (1994, p. 106) states that, reality is made up of processes of going on, doing, meaning, sensing, being, happening and becoming. According to Matheson (2005, p. 66), transitivity concentrates on each clause in the text, it asks who are the actors, who are the acted on, and what processes are engaged in that action. Halliday says that "the key for understanding the ideational meaning of texts, is transitivity" (1978, p. 132). In traditional English grammar, lexical verbs can be transitive or intransitive verbs. In a transitive verb, there is a conveyance of activity from the agent to the object or the action specified by the verb has a grammatical connection with the object. In an intransitive verb, the action or state of the verb stays with it and does not impact any other person or thing. Transitivity types also identify the field of discourse in novels. Transitivity is a fundamental and dense semantic idea in Halliday. It is a part of the ideational ability of language, thus, a main device in the inquiry of representation (Toe, 2000, p. 8). Through an application of transitivity analysis, we can notice how the discourse marker describes a character in the novel through language select. Transitivity analysis also becomes a bridge to discover themes which the discourse marker selected. Fowler, in pointing to Halliday, illustrates that transitivity is the basis of representation; it is the method the clause is used to analyze situations and events as being of specific types. The transitivity system, then, makes it potential to depict an event from various angles, and thus can be said to refer to different ideological perspectives (Fowler, 1991, p. 71). SFG is the study of the relation between language and its function in social settings. SFG considers grammar as a source of making meaning and confirms on the interconnectedness of form and meaning. Transitivity in this sense must not be confused with the term used to depict the transitive or intransitive nature of various verbs. [T]ransitivity includes looking at language used to describe: "what happens, who are the participants, and what are the circumstances" (Beard, 2000, p. 30). To sum up, six process types of transitivity system are, according to Halliday, recognized via material, mental, behavioral, relational, verbal and existential. Below is a table that summarizes all kinds of process and their general category meaning, adopted from Halliday's work (2004).

Table 2. Six process types of transitivity system by Halliday

\begin{tabular}{|l|l|l|l|}
\hline Process types & "Meaning of category" & "Direct participants" & $\begin{array}{l}\text { "Oblique } \\
\text { participants" }\end{array}$ \\
\hline
\end{tabular}




\begin{tabular}{|l|l|l|l|}
\hline Material & $\begin{array}{l}\text { doing } \\
\text { happening" }\end{array}$ & "actor, goal" & $\begin{array}{l}\text { "recipient, client, } \\
\text { attribute" }\end{array}$ \\
\hline Behavioral & behaving & behaver & Behavior \\
\hline Mental & Feeling & $\begin{array}{l}\text { sensor, } \\
\text { phenomenon }\end{array}$ & addressee, verbiage \\
\hline Verbal & Saying & sayer, target & $\begin{array}{l}\text { "attributor } \\
\text { Assigner" }\end{array}$ \\
\hline Relational & $\begin{array}{l}\text { attributing } \\
\text { identifying }\end{array}$ & value" attribute, token & existent \\
\hline existential & existing & &
\end{tabular}

\subsubsection{Labov's model of narrative analysis (macro-level/superstructure)}

In order to arrive at the sociolinguistic analysis of this study, each of the sentences in the narrative was assessed (valued) according to Labovian narrative units. According to Labov, narrative can be defined as a way to recapitulate past experience by corresponding the verbal sequence of clauses with the sequence of events that have actually happened. He examines the nature of the linguistic devices used to notice verbal skills while assessing an experience during narrative. Labov evolved a theoretical framework for analyzing these experiments (1972, p. 359). In the sociolinguistic analysis of British narratives, we adopted Labov's framework to the structure of narratives. Furthermore, the social variable of gender was taken as the variables in analyzing the linguistic structure of the narratives. Following Labov's hypothesis that language varies according to social variables such as age, gender and social class, our objective in this study is to show the impact of gender on language variation and change. According to him, linguistic features like syntactic, lexical, etc., are analyzed in relation to gender in order to understand the linguistic variation between the language of the novels. It is important, to understand narratives, to analyze their internal structure in relation to their function, so as to relate the formal properties of narratives to their functions (Labov \& Waletzky, 1967, p. 12). Labov and Waletzky assert that a fully formed narrative consists of six parts, each consisting of a set of clauses of a general functional type that can be recognized through its use of particular lexical and grammatical devices, which form distinct parts in the narrative (Labov, 1997, p. 403). The six parts are: abstract, orientation, complicating action, evaluation, resolution and coda, each of them has a distinct form and function.

An abstract refers to an initial clause in a narrative that narrates the entire sequence of events of the narrative. Labov uses this term to refer to the introductory section of the narrative. The next section is called 'orientation'. An orientation clause gives the reader information about the time and place of the events of narrative, the identities of the participants and their initial demeanor. It is necessary, for the story to be understandable and valid, the reader be informed of the time and place in which the narrative unfolds. Following orientation is the 'complicating action'. Complicating action refers to the actual events of the narrative. It composed of clauses that represent a chain of past events up to the climax. It is concerned with responding the question, "And what happened then?". The fourth category of Labov's model is called "evaluation". Evaluation of a narrative event usually takes place before the result and serves to highlight the fascinating or unusual point(s). Evaluation indicates to the point, or reason at which narrative is listed. After the evaluation comes what Labov called the "resolution" or "result"; this, essentially, is the conclusion. At this point, the tension decreases suddenly, and the narrator points out that the story has come to an end, and that the last event has took place. Result or resolution explains what eventually happened. Ultimately, there might be "coda". With "coda", Labov 
means that the narrator indicates the importance of the story by relating it to daily life, or to other actions or events that fall outside the framework of the story. It is to indicate that the story has finished. Coda may not always be present. It can also be present without explicitly mentioning it. All the definitions of the abovementioned categories have taken from Labov (1972, pp. 363-393).

\section{Data Analysis}

\subsection{Qualitative Analysis: Transitivity and Passivization (micro-level)}

Sample 1 We Are Not Alone

\section{Extract 1}

\section{Orientation}

"One cold gusty night in December a boy rang the bell of the doctor's house in Shawgate, and when Susan came to the doctor left word that there had been an accident to a dancer at the local theatre and would the doctor please come at once". Bestowing, her usual skeptical scrutiny on such a messenger, Susan pressed for further details, but the boy could give none and ran off home, leaving her to waken David from the peacefulness of a last pipe in the surgery. "He had had a busy day and was tired, but when she reported the message he nodded vaguely and began butting things in his bag."

Transitivity indicates to how meaning is represented in the clause by how text makers encode in language their mental picture of reality. In the extract above, the sentence 'a boy rang the bell', the material process 'rang' involves that the participant (the actor) which is 'boy' doing something to another participant (the goal) which is 'bell'. In this sentence, the writer puts focus on the doer of the action. In 'Susan came to the door', the material process 'came' is shown by the agent 'Susan' who was trying to know more details about the message as shown by the goal 'door'. The process that depicts something exists or happens is existential process as in the sentence 'there had been an accident'. The existential process 'had been' involves one participants - the existent, which refers to the 'accident' that happened to the dancer at the local theatre. The sentence 'the boy ran off home' shows material process. The process 'ran off' shows the narrator's focus on the actor 'the boy' and how he escaped to his house (goal) without giving any details about the accident. In attributive relational clause 'he had had a busy day', the attribute 'busy day' is ascribed to a participant called carrier 'he' which is followed by 'had' (possessive) to describe the condition of the doctor on that arduous day. The material process 'reported' in the sentence 'she reported the message' is shown by the actor 'she' who reported a word to the doctor as shown by the goal 'message'. The sentence "... began putting things in his bag" consists of two processes. On the one hand, the material process 'began' demands that the agent 'he' doing something to another participant which is the goal 'putting things'. On the other hand, the goal is followed by the phrase 'in his bag' that is a circumstance of location to express the place where the doctor puts his things.

Sample 2 NOR M?

Extract 2

Orientation

"It was the spring of 1940. Mrs. Beresford gave him a quick glance and then busied herself by knitting at a furious rate. She said after a minute or two: "Any news in the evening paper?" Tommy 
said: "The Blitzkrieg is coming, hurray, hurray! Things look bad in France." Tuppence said: "It's a depressing world at the moment."

The transitivity system can make a clause more comprehensible because the reader will know the certain process in the clause. The narrator identified the time of the events of the novel through the activation relational clause 'it was the spring of 1940.' In this identifying clause, the 'it' is identified which is followed by the circumstantial relational process 'was', while 'the spring of 1940' is the circumstance of time which has been used to add more details to the clause. The material clause "Mrs. Beresford gave him a quick glance..." has been used in the first part of the above extract to focus on the actor 'Mrs. Beresford' who is doing the action 'gave'. The action is extended to the goal 'him' and the circumstance of matter 'quick glance' which functions to give or add more information about the clause. In the clause "She said after a minute or two: "Any news in the evening paper?" Tommy said: "The Blitzkrieg is coming", the activation verbal process has been used twice. The first one consists of the sayer 'she' (referring to Mrs. Beresford) which is followed by the verbal verb 'said' and the circumstance of time 'after a minute or two', and the verbiage "any news in the evening paper" which is the content of what is said. The sentence can be interpreted as that; Mrs. Beresford asked her husband if there was any news in the evening newspaper. The second includes the primary clause 'Tommy said' which contains of the sayer 'Tommy' and the verbal process 'said', and the secondary clause 'The Blitzkrieg...' which represents the verbiage. The verbiage is the participant that matches to what is said. Moreover, the last clause Tuppence said: "It's a depressing..." of the first part of the extract is also the verbal one, consisting of two participants: the sayer 'Tuppence' which is extended to the verbal verb 'said' and the verbiage 'It's a depressing...' Mrs. Beresford describes the world as a sorrowful world at that time.

\subsection{Quantitative Analysis}

\section{A. Quantitative analysis of Halliday's Transitivity in the male novel 'We Are Not Alone'}

The process types of Halliday's transitivity are now analyzed quantitatively in table (5). The total use of these processes is (100). Among the six process types, the material gets the highest rank by the count (36) and percentage (36\%). The reason of this high rank is justified by the importance of the action, that is, the novel depicts the tragic consequences of hatred against foreign in England. So, the use of material process is important to interpret the action. The lowest rank goes to behavioral process, by having (3) and (3\%). Then, we have mental and relational with its four types (attributive, identifying, possessive, circumstantial) gaining the second rank, by its scoring (19) and percentage (19\%). The narrator relies on the minds, thoughts, and feelings of others towards the events of the First World War, which is reflected in his novel, and this achieved through the use of mental process that shows how people think about the war. The reason of the relational process is justified by describing the major axis of the study. Verbal process type gets the third rank, by its count (15) (15\%). The role of verbal process is justified because the narrator tends to support the theme of the novel by highlighting the content of the sayer, which has a direct impact on the reader. The last process is existential, which also has a low score in relation to the other types, scoring (8) (8\%). The lowest rank of behavioral and existential is justified due to these two processes are frequently used in the context of conversation. The analysis of these results are illustrated in table (3).

Table 3. Quantitative Analysis of Transitivity in the novel 'We Are Not Alone'

\begin{tabular}{|l|c|l|l|}
\hline $\mathrm{N}$ & Process type & Count & $\%$ \\
\hline 1 & Material & 36 & $36 \%$ \\
\hline 2 & Mental & 19 & $19 \%$ \\
\hline
\end{tabular}




\begin{tabular}{|l|l|l|l|l|}
\hline \multirow{3}{*}{3} & \multirow{2}{*}{ Relational } & Attributive & 8 & $8 \%$ \\
\cline { 3 - 5 } & & Identifying & 3 & $3 \%$ \\
\cline { 3 - 5 } & & Possessive & 7 & $7 \%$ \\
\cline { 3 - 5 } & Circumstantial & 1 & $1 \%$ \\
\hline 4 & \multicolumn{2}{|c|}{ Verbal } & 15 & $15 \%$ \\
\hline 5 & \multicolumn{2}{|c|}{ Behavioral } & 3 & $3 \%$ \\
\hline 6 & \multicolumn{2}{|c|}{ Existential } & 8 & $100 \%$ \\
\hline & Total & 100 & \\
\hline
\end{tabular}

\section{B. Quantitative analysis of Passivization in the male novel 'We Are Not Alone'}

Table (4) shows the frequencies and percentages of each micro-linguistic categories in the Quirk grammatical system of the British sample that are examined in the qualitative analysis. The two adopted categories, activation and passivation, are analyzed quantitatively. The total number of these categories is (100). Starting with the highest rank, activation gets this rank by scoring (94) and percentage (94\%). The British novelist tends to use activation more than passivation category because of his prominent role in conveying the events which reflecting on his character of the novel. On the contrary, passivation is also used, but a very low rate than activation, scoring (6) and percentage (6\%). But, this does not mean that passivation has no important role, instead, this is due to the fact that the social actor refers to one person, who is the narrator.

Table 4. Quantitative Analysis of Passivazation in the male novel 'We Are Not Alone'

\begin{tabular}{|l|l|l|l|}
\hline $\mathrm{N}$ & Category & Count & $\%$ \\
\hline 1 & Activation & 94 & $94 \%$ \\
\hline 2 & Passivation & 6 & $6 \%$ \\
\hline & Total & 100 & $100 \%$ \\
\hline
\end{tabular}

\section{Quantitative analysis of Halliday's Transitivity in British female novel 'N OR M'}

Halliday's transitivity system and its process types are analyzed quantitatively in table (5). (172) is the total count of all the processes that are examined in the British sample. To compare these processes with each other, starting with the high rank, which the material process type gets it by its count of (50) and percentage (29.06\%). The British novelist tends to use this process to emphasize on the topic of her novel, since World War II is an actual event, so the material process is important for such a subject. Relational, with its four kinds, scores the second rank, however, only the first two types, attributive and identifying, have appreciable counts, recording (21) (12.20\%) and (20) (11.625), sequentially. The other types, possessive and circumstantial, record (2) (1.16\%) and (4) (2.32\%), respectively. The reason for this rank is justified by describing the features of the narrator who reflects it on her characters. The verbal process scores the third rate by the count (32) and percentage $(18.60 \%)$. This process is justified due to the narrator tends to confirm her argumentation by depending on ambiguous speech as a method of excitement and suspense for the reader. Then, the mental process comes, which is very close by its count and percentage from the verbal, scoring (31) and percentage (18.02\%). The narrator depends on this process through transferring the suffering of people from the war and the political conflict that it caused between the major countries. The fifth rank is pertained to the existential process as having the count (11) (6.39\%). Finally, the lowest rank goes to the behavioral process, as record (1) and percentage $(0.58 \%)$ from the total number. The analysis is clarified in table (5). 
Table 5. Scores and percentages of Transitivity in British novel 'N OR M?'

\begin{tabular}{|l|l|l|l|l|}
\hline $\mathrm{N}$ & \multicolumn{2}{|l|}{ Process type } & Count & $\%$ \\
\hline 1 & \multicolumn{2}{|c|}{ Material } & 50 & $29.06 \%$ \\
\hline 2 & \multicolumn{2}{|c|}{ Mental } & 31 & $18.02 \%$ \\
\hline \multirow{4}{*}{3} & \multirow{3}{*}{ Relational } & Attributive & 21 & $12.20 \%$ \\
\cline { 3 - 5 } & Identifying & 20 & $11.62 \%$ \\
\cline { 2 - 5 } & Possessive & 2 & $1.16 \%$ \\
\cline { 2 - 5 } & Circumstantial & 4 & $2.32 \%$ \\
\hline 4 & Verbal & 32 & $18.60 \%$ \\
\hline 5 & Behavioral & 1 & $0.58 \%$ \\
\hline 6 & Existential & 11 & $6.39 \%$ \\
\hline & \multicolumn{2}{|c|}{ Total } & 172 & $100 \%$ \\
\hline
\end{tabular}

\section{Quantitative analysis of Passivization in the British female novel 'N OR M?'}

The two micro-linguistic categories of Quirk's system are now analyzed quantitatively in table (6). The total score is (172). Activation gets the first rank by scoring (153) and percentage (88.95\%), which is much higher than the passivation, recording (19) (11.04\%). The reason for this higher rank is the importance of the doer of the action who is present in the text to show her or his role.

Table 6. Scores and percentages of Passivization in British novel 'N OR M?"

\begin{tabular}{|l|l|l|l|}
\hline $\mathrm{N}$ & Category & Count & $\%$ \\
\hline 1 & Activation & 153 & $88.95 \%$ \\
\hline 2 & Passivation & 19 & $11.04 \%$ \\
\hline & Total & 172 & $100 \%$ \\
\hline
\end{tabular}

\section{3 Comparison \& Discussion of Results}

\section{A. Statistical Analysis of Halliday's Transitivity in the two British samples (M-F)}

The application of the chi-square test to transitivity in the light of the six process types of (material, mental, relational, verbal, behavioral, and existential) is tackled, as shown in the table (7). To know whether there is a difference or not between the male and female in using these process types, take each process separately and make a statistical horizontal comparison. Starting with the first rank, the material process scores in the British male novel (36\%), and (29.06\%) in the British female one. To make a comparison between the two variables, applying the chi-square test. The computed chi-square value for this process is (2.28) with p-value (0.13), thus, the computed value is lower than the tabulated chi-square value (3.84), and the p-value is higher than (0.05). As such, there is a statistically insignificant difference in the use of the material process in each of the male and female novel. Then, we have the mental process, its calculated chi-square is (2.88), and p-value is (0.09). Being lesser than the tabulated value (3.84) and above of the level (0.05), so, there is no difference between the two variables. These values lead to achieving the null hypothesis, as there is a similarity between male and female in terms of the two processes; material and mental. Thus, the alternative hypothesis is rejected. Then, two modes of relational process (attributive and identifying) come next. The attributive relational process has the calculated chi-square value (5.83) and its p-value is (0.02). Per contra, the identifying mode has (12.57), as the computed chi-square value and (0.00) as its p-value. In both cases, the calculated chi-square is greater than the tabulated value (3.84), and the p-value is lower than 
(0.05). This supports the alternative hypothesis, as there is a significant difference between male and female in using these two modes. But, in the other two modes of relational process (possessive and circumstantial), there is no difference between the two variables, then, the null hypothesis is verified. To take each one, first, the calculated chi-square value of the possessive process is (2.78) and p-value (0.096), and (1.8) as a computed chi-square value with (0.18) as a p-value, for circumstantial process. These values of the two processes record a rate low than (3.84) and higher than (0.05). By the analysis of the verbal process, the case is different. The process scores the percentage (15\%) in the British male novel, and (18.60\%) in the British female novel. To compare the two, the researcher will apply the Chi-square test, the calculated chi-square value is (6.15) with p-value (0.013). As a result, the computed value is higher than the tabulated one (3.84), and the p-value is lower than (0.05). So, there is a significant difference in using the verbal process in each of the variables (male and female). In this case, the null hypothesis is rejected and the alternative one is accepted. In applying the chi-square test of the last two processes; behavioral and existential, it is observed that the null hypothesis is verified, as there is a similarity between male and female in terms of the behavioral and existential processes. To take each one separately, firstly, the calculated chi-square value of behavioral is (1.0) with p-value (0.32), and the existential process counted (0.47) as its computed chi-square value, with its p-value (0.49). These values record a rate less than the tabulated value (3.84), and higher than (0.05).

Table 7. Chi-Square Test of Process Types of Transitivity in the Two British Samples (M-F)

\begin{tabular}{|c|c|c|c|c|c|c|c|c|}
\hline \multirow{3}{*}{$\begin{array}{l}\text { Social } \\
\text { Variable }\end{array}$} & \multirow{3}{*}{\multicolumn{2}{|c|}{$\begin{array}{l}\text { Process } \\
\text { Type }\end{array}$}} & \multicolumn{4}{|c|}{ British novels } & \multirow{3}{*}{ Chi-sq } & \multirow{3}{*}{ P-Value } \\
\hline & & & \multicolumn{2}{|l|}{$\mathrm{M}$} & \multicolumn{2}{|l|}{$\bar{F}$} & & \\
\hline & & & Count & $\%$ & Count & $\%$ & & \\
\hline \multirow[b]{9}{*}{ లే } & \multicolumn{2}{|c|}{ Material } & 36 & $36 \%$ & 50 & $29.06 \%$ & 2.28 & 0.13 \\
\hline & \multicolumn{2}{|c|}{ Mental } & 19 & $19 \%$ & 31 & $18.02 \%$ & 2.88 & 0.09 \\
\hline & \multirow{4}{*}{ 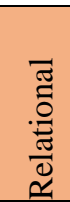 } & Attributive & 8 & $8 \%$ & 21 & $12.20 \%$ & 5.83 & 0.02 \\
\hline & & Identifying & 3 & $3 \%$ & 20 & $11.62 \%$ & 12.57 & 0.00 \\
\hline & & possessive & 7 & $7 \%$ & 2 & $1.16 \%$ & 2.78 & 0.096 \\
\hline & & Circumstantial & 1 & $1 \%$ & 4 & $2.32 \%$ & 1.8 & 0.18 \\
\hline & \multicolumn{2}{|c|}{ Verbal } & 15 & $15 \%$ & 32 & $18.60 \%$ & 6.15 & 0.013 \\
\hline & \multirow{2}{*}{\multicolumn{2}{|c|}{$\begin{array}{l}\text { Behavioral } \\
\text { Existential }\end{array}$}} & 3 & $3 \%$ & 1 & $0.58 \%$ & 1.0 & 0.32 \\
\hline & & & 8 & $8 \%$ & 11 & $6.39 \%$ & 0.47 & 0.49 \\
\hline \multicolumn{3}{|l|}{ Total } & 100 & $100 \%$ & 172 & $100 \%$ & & \\
\hline
\end{tabular}

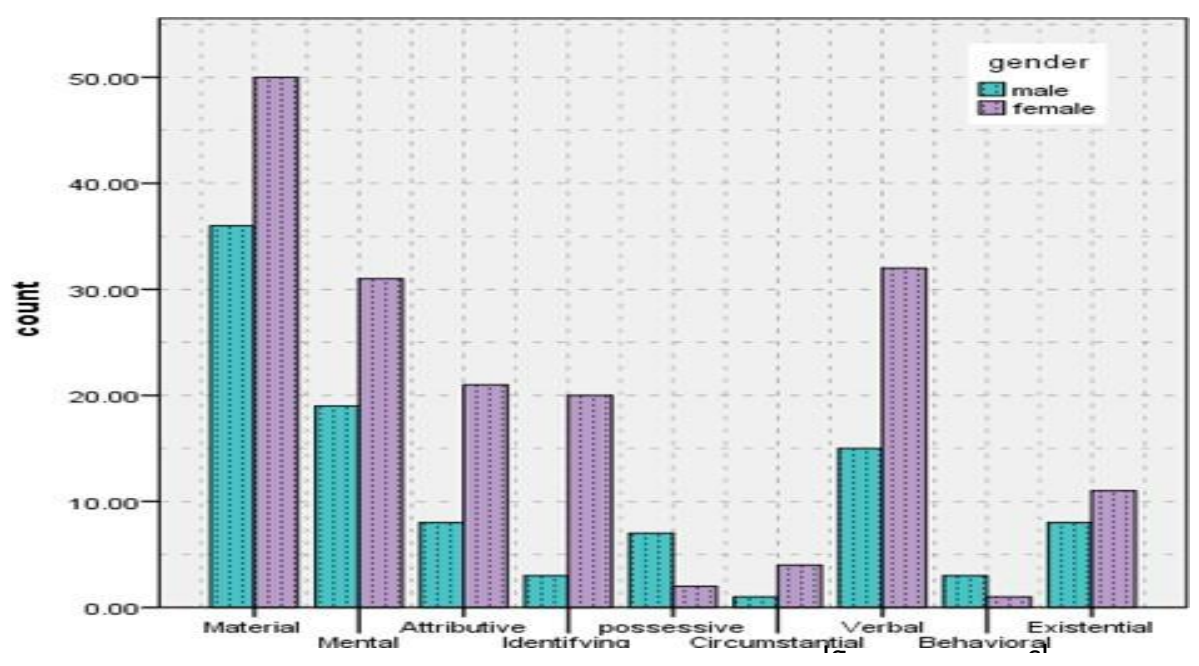

Figure 1. Distribution of Process Types in the two British Samples (M-F) 


\section{B. Statistical Analysis of Passivization in the two British Samples}

Table (8) adduces the quantitative statistical analysis of passivization in the two British samples, applying the chi-square test and its p-value for each category of passivization to be compared in the two British samples. Starting with activation, the calculated chi-square value is (14.09) and the p-value is (0.000). It is noted that the computed chi-square value is larger than the tabulated value (3.84), and fewer than (0.05); hence, a difference exists among the two variables (male and female). Then, the alternative hypothesis is achieved and the null one is rejected. The second category, passivation, has the calculated chi-square value (6.67) and p-value (0.009). Being higher than the tabulated chi-square value (3.84) and lower than the standard level (0.05), the null hypothesis is untrue and the alternative one is verified, so the result of this analysis is significant. Therefore, there is a difference between male and female concerning the passivization category.

Table 8. Chi-Square Test of Passivization in the two British samples (M-F)

\begin{tabular}{|l|l|l|l|l|l|l|l|}
\hline \multirow{2}{*}{$\begin{array}{l}\text { Social } \\
\text { Variable }\end{array}$} & \multirow{3}{*}{ Categoty } & \multicolumn{3}{|l|}{ British novels } & \multirow{2}{*}{ Chi-sq } & \multirow{2}{*}{ P-Value } \\
\cline { 3 - 7 } & & \multicolumn{3}{|c|}{$\mathrm{M}$} & $\mathrm{F}$ & \\
\cline { 3 - 7 } & & Count & $\%$ & Count & $\%$ & & \\
\hline \multirow{2}{*}{ Gender } & Activation & 94 & $94 \%$ & 153 & $88.95 \%$ & 14.09 & 0.000 \\
\hline Total & Passivation & 6 & $6 \%$ & 19 & $11.04 \%$ & 6.76 & 0.009 \\
\hline
\end{tabular}

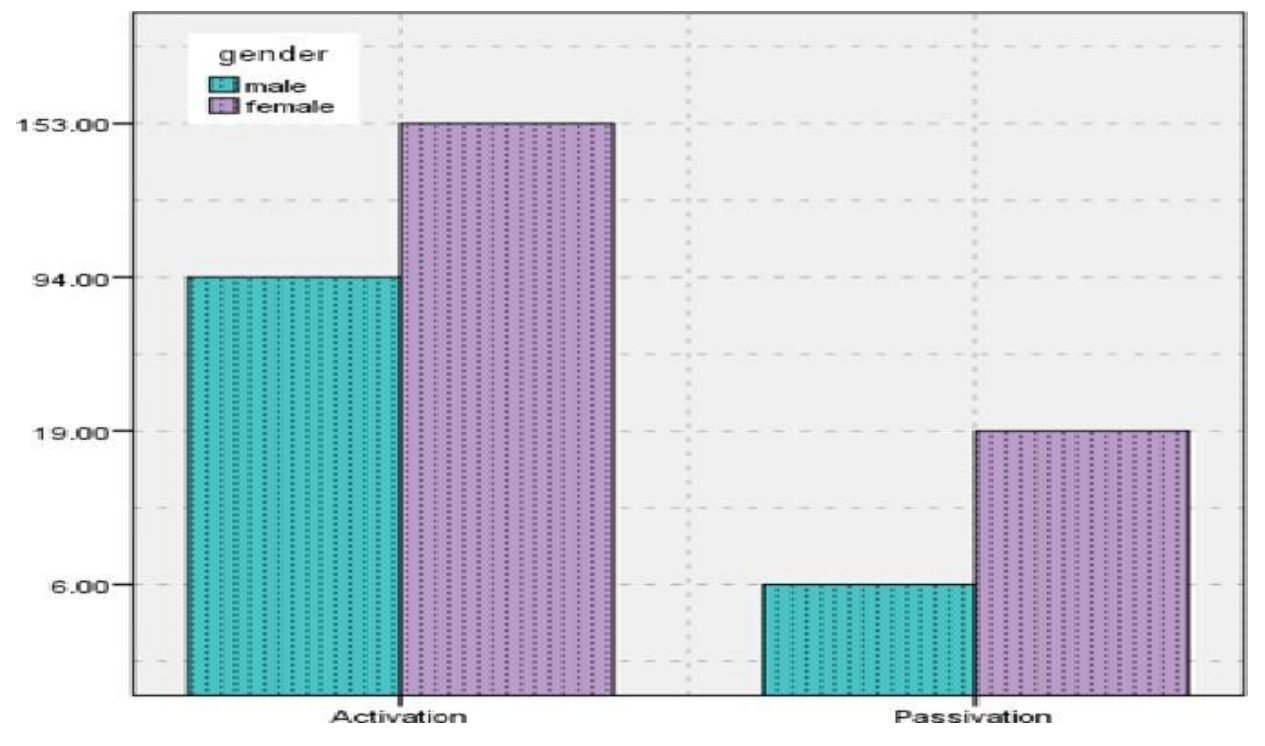

Figure 2. Distribution of Passivization in the two British Samples (M-F)

\section{Conclusion}

The current study summarizes the findings by defining its conclusions. This study has tackled some linguistic choices in language of novels from a sociolinguistic point of view in the two British novels. The main conclusions arrived at by this research can be summed up in the following points: the social variable of gender influences the linguistic choices in language of the novels, so, the first hypothesis is achieved; differences and similarities are detected between each of the British male and female novel, in terms of the use of linguistic choices, then, the second and third hypothesis are verified; both male and female narrators employ the activation category more frequently than the other grammatical category of passivation. However, female narrator tends to use the activation category more than the male one. 


\section{References}

Cameron, D., F. McAlinden and K. O'Leary. (1988). 'Lakoff in context: the social and linguistic functions of tag questions', in J. Coates and D. Cameron (eds), Women in their Speech Communities. London and New York: Longman.

Chambers, J.K. (1995). Sociolinguistic Theory. Linguistic Variation and Its Social Significance. Oxford: Blackwell.

Cheshire, J. (2002). Sex and gender in variationist research, in J.K. Chambers, P. Trudgill, and N. Schilling-Estes (eds), The Handbook of Language Variation and Change. Malden and Oxford: Blackwell.

Chomsky, N. (2006). Aspects of the Theory of Syntax. Cambridge, MA: MIT Press.

Creswell, J.W. (2012). Educational research: Planning, Conducting, and evaluating quantitative and qualitative research. $4^{\text {th }}$ ed. Boston, MA: Pearson.

Creswell, J.W. (2014). Research Design: Qualitative, Quantitative and Mixed Methods Approaches. $4^{\text {th }}$ ed. Thousand Oaks, CA: Sage.

Fowler, R. (1991). Language in the news: Discourse and ideology in the press. London: Routledge.

Halliday, M.A.K. (1978). Language as a Social Semiotic. London: Arnold.

Halliday, M.A.K. (1994). An Introduction to Functional Grammar. London: Edward Arnold.

Halliday, M.A.K. (2004). An Introduction functional grammar. $3^{\text {rd }}$ ed. London: Hodder Arnold.

Hudson, R. A (1996). Sociolinguistics. $2^{\text {nd }}$ Edition. Cambridge: Cambridge University Press.

Labov, W. (1990). The Intersection of Sex and Social class in the course of linguistic change. Language variation and Change.

Labov, William (1972b). Sociolinguistic Patterns. Philadelphia: University of Pennsylvania Press.

Llamas, C \& et al. (2007). The Routledge Companion to Sociolinguistics. London and New York.

Meyerhoff, M. (2006). Introducing Sociolinguistics. London and New York: Routledge.Pearson Longman.

Quirk, Randolph \& et al. (1985). A comprehensive Grammar of the English Language. London.

Swann, J., et al. (2004). A Dictionary of Sociolinguistics. Edingburgh: Edingburgh University Press.

Tagliamonte, Sali A. (2012). Variationist Sociolinguistics: Change, Observation, Interpretation. Malden and Oxford: Wiley-Blackwell.

Toe, P. (2000). Racism in the news: A Critical Discourse Analysis of news reporting in two Australian newspapers Discourse \& Society. Vol. 11.

Van Herk, G. (2012). What Is Sociolinguistics? John Wiley \& Sons Ltd, The Atrium, Southern Gate, Chichester, West Sussex, PO198SQ, UK.

Veselovska, Ludmila, and Joseph Edmonds. (2011b). English Syntax: Syllabi, Examples and Exercises. Olomouc: Univerzita Palackeho v Olomouci.

Wardhaugh, R. (2006). An Introduction to Sociolinguistics. $5^{\text {th }}$ ed. Blackwell Publishing Ltd 1.

\section{AUTHOR BIODATA}

Hawra Taher Hussein is a Currently a master's student in English Language at Karbala University-Iraq.

Hussein Musa Kadhim Al-Nasrawi is aspecialist in comparative linguistics in English Language Dept., at Karbala University-Iraq. 